\title{
Diversity and Characterization of Plant Growth Promoting Rhizobacteria Associated with Wheat (Triticum aestivum) Rhizosphere in North-Western Himalayan State of Himachal Pradesh in India
}

\author{
Vijay Kumar ${ }^{1 *}$, Nivedita Sharma ${ }^{2}$ and M. A. Kuchay ${ }^{3}$ \\ ${ }^{1}$ Career Point University, Hamirpur-176041 (Himachal Pradesh), India \\ ${ }^{2}$ Department of Basic Sciences, Dr. Y.S. Parmar University of Horticulture and Forestry \\ Nauni, Solan-173230 (Himachal Pradesh), India \\ ${ }^{3}$ Collage of Horticulture and Forestry, Neri (Hamirpur), India \\ *Corresponding author
}

\section{A B S T R A C T}

\begin{tabular}{l} 
Ke y w o r d s \\
Wheat, \\
Rhizosphere, \\
PGPR, PGP \\
attributes, Diversity \\
Article Info \\
$\begin{array}{l}\text { Accepted: } \\
\text { 05 February } 2020 \\
\text { Available Online: } \\
\text { 10 March } 2020\end{array}$ \\
\hline
\end{tabular}

Keeping in view the scare knowledge of the composition of bacterial diversity associated with roots of wheat, the present study was undertaken to explore its diversity \& investigate their role in plant growth promotion. Present study revels, the diversity of bacterial isolates from soils under wheat cultivation in districts of Solan of Himachal Pradesh. Phenotypic and physiological characteristics of the PGPR isolates were record to categorize and identify the bacteria. Sixty different rhizobacteria isolates were recovered from different locations of the district of which some were rainfed and some were irrigated. The characteristics of the bacterial isolates were determined using the colony morphology, gram staining as well as biochemical properties. These isolates were than tested for different PGPR traits, such as production of lytic enzymes, siderophore, P-solubilization, Ammonia and HCN.

\section{Introduction}

\section{Wheat}

Wheat (Triticum aestivum) is the major grain that sustains humanity. Wheat grown in temperate climate and it is staple food for $35 \%$ of world's population. On other hand, it provides more calories and protein in the diet than any other crop (Laegreid et al., 1999). Wheat (Triticum astivum L) are members of Graminae family. Currently, India is second largest producer of Wheat in the world after China with about $12 \%$ share in total world wheat production. Himachal Pradesh - a north-western Himalayan state of India is one 
of the major contributors for wheat production of India (Mishra et al., 2007). In 2016, world production of wheat was 749 million tonnes, making, it the second mostproduced cereal after maize (1.03 billion tonnes), with more than rice (499 million tonnes) (United Nations, Food and Agriculture Organization. 2016).

PGPR are beneficial for plant growth and also referred as Yield Increasing Bacteria (YIB). They affect plant growth and yield in a number of ways and enhancement reproductive growth is documented in a range of crops like cereals, pulses, ornamentals, vegetables, plantation crops and some trees (van Loon et al., 1998). Since rhizosphere of any crop is found rich in PGP rhizobacteria, therefore it becomes important to isolate potential microorganisms from rhizosphere of wheat from different sites \& assess their diversity \& role in PGP activities.

The plant growth promoting (PGP) effect of the PGPR is mostly explained by the release of metabolites directly stimulating growth. Several mechanisms have been postulated to explain how PGPR benefit the host plant. These include:(a) the ability to produce plant growth regulators or phytohormones such as indole acetic acid (IAA), cytokinins, and gibberellins (Glick,1995; Marques et al., 2010); (b) enhancing asymbiotic $\mathrm{N}_{2}$ fixation (Khan et al., 2006); (c) solubilizing inorganic phosphate and mineralization of organic phosphate and/or other nutrients (Glick, 1995); (d) antagonistic effect against phytopathogenic microorganisms by production of siderophores, Interest in the beneficial rhizobacteria associated with cereals has increased recently and several studies clearly demonstrated the positive and beneficial effects of PGPR on growth and yield of different crops especially wheat at different environment under variable ecological conditions. Keeping in mind the study was planned to isolate the native strains from rhizosphere of wheat grown on different soils of Solan district of Himachal Pradesh. These bacterial isolates were characterized and screened in vitro for PGP potentials.

\section{Materials and Methods}

\section{Sample collection and isolation of bacteria}

Wheat (Triticum aestivum L.) plant rhizospheric soil samples were collected from different sites of Solan district of Himachal Pradesh. Samples were collected individually in sterilized polythene bags. Rhizospheric bacteria were isolated from $1 \mathrm{~g}$ soil tightly adhering to the root by serial dilution plating on Luria-Bertani agar (LB), King's B agar and Nitrogen- free agar medium (Jenson medium) agar plates as described (Somasegaran and Hoben,1994). The plates were incubated at $28 \pm 2{ }^{0} \mathrm{C}$ till the appearance of bacterial colonies. Individual colonies were picked and streaked on respective plates for further purification.

\section{Biochemical characterization}

Colony morphology, size, color, shape, and growth pattern were recorded after $24 \mathrm{~h}$ of growth on different nutrient agar medium, plates were incubated at $28 \pm 2^{0} \mathrm{C}$ as described by Somasegaran and Hoben (1994).

\section{Colony morphology and pigment production}

Colony morphology (form, elevation, margin, shape, surface) and the production of pigment was checked on King's B agar at $28 \pm 2{ }^{0} \mathrm{C}$ after 24 to $48 \mathrm{~h}$.

\section{Gram staining}

Four different reagents in the order of Crystal violet, Gram's iodine, alcohol/acetone destaining reagents, and safranin were used to 
identify and classifying bacteria.

The gram's reaction was performed as described (Aneja, 2003).

\section{Catalase test}

Catalase production was checked by placing a drop of $\mathrm{H}_{2} \mathrm{O}_{2}$ onto the bacterial colony on a glass slide (Taylor et al., 1972).

\section{Bio assays for Plant Growth Promoting Traits}

\section{P- solubilization}

Solubilization of insoluble Phosphate. Each bacterial culture was spot inoculated in the center of agar plates containing tricalcium phosphate as insoluble phosphate source (Pikovskaya's, 1948). The plates were incubated at $28 \pm 2^{\circ} \mathrm{C}$ for $7-10$ days and observed for the formation of halo zone around the colonies.

\section{Siderophores production}

Nutrient agar medium was used for the production of siderophore with slight modification (Meyer and Abdallah, 1978). 0.5 $\mathrm{ml}$ of $18 \mathrm{~h}$ old inoculums of PGPR's isolates was added to $100 \mathrm{ml}$ of king's B medium in $250 \mathrm{ml}$ flask. The flask were incubated at $28^{0}$ $\mathrm{C}$ for $72 \mathrm{~h}$ under shake condition on rotary shaker. The supernatant was harvested by centrifugation at $10,000 \mathrm{rpm}$ for 20 minutes at $4{ }^{0} \mathrm{C}$ and store at $4{ }^{0} \mathrm{C}$.

\section{Qualitative assay}

Siderophores production was detected by chrome azurol-S (CAS) plate assay method with slight modification (Schwyn and Neilands, 1987). $25 \mathrm{ml}$ of CAS dye (prepared by mixing $1.5 \mathrm{ml}$ of $1 \mathrm{mM} \mathrm{FeCI}_{3}, 6 \mathrm{H}_{2} \mathrm{O}$ in 10 $\mathrm{mM} \mathrm{HCl}+7.5 \mathrm{ml}$ of $2 \mathrm{mM}$ of CAS stock solution dissolved in $50 \mathrm{ml}$ of HDTMA, add
$30 \mathrm{ml}$ piperazine solution $(4.307 \mathrm{~g}$ piperazine was dissolved in $30 \mathrm{ml}$ water and $6.75 \mathrm{ml}$ of concentrated $\mathrm{HCl}$ was added to make $\mathrm{pH}$ 5.6) into it and final volume was made to $100 \mathrm{ml}$ with distilled water) was mixed with $250 \mathrm{ml}$ of nutrient agar and mixed well before pouring. $100 \mu \mathrm{l}$ of $72 \mathrm{~h}$ old culture supernatant of each test bacteria was placed on prepoured chrome azurol-S agar (CAS) plates. Plates were incubated at $28^{0} \mathrm{C}$ for $72 \mathrm{~h}$. Production of siderophore was expressed in terms of $\mathrm{mm}$ diameter of pinkish/orange halo produced around the bit/well at $28^{\circ} \mathrm{C}$ in $72 \mathrm{~h}$.

\section{$\mathrm{HCN}$}

All the isolates were screened out for the production of hydrogen cyanide $(\mathrm{HCN})$ (Bakker and Schippers, 1987). Cultures were streaked on prepoured plates of nutrient agar medium amended with $1.4 \mathrm{~g} / \mathrm{l}$ glycine. Whatman No.1 filter paper strip were soaked in 0.5 per cent picric acid followed by 2 per cent sodium carbonate and were placed in the lid of each petriplates. Petriplates were sealed with parafilm and were incubated at $28^{\circ} \mathrm{C}$ for four days. Uninoculated control with picric acid paper strips was kept for comparison of results. Plates observed for change of color of filter paper from yellow (-) to brown (+++) to dark brown $(++++)$. Intensity of color developed indicated as high production of volatile $\mathrm{HCN}$.

\section{Ammonia production}

Ammonia production was checked according to Lata and Saxena (2003). All isolates were grown in peptone water $(5 \mathrm{ml})$ in tubes. Tubes were incubated at $28^{\circ} \mathrm{C}$ for 4 days. $1 \mathrm{ml}$ of Nessler's reagent was added to each culture tube. Presence of faint yellowish to brown color $(+)$ indicated small amount of ammonia and deep yellow (++) to brown color $(++++)$ indicated large amount of ammonia production. 


\section{Lytic enzymes}

\section{Protease}

All isolates were screened out for production of protease by well plate assay (Mehta and Singh, 2006) on skim milk agar (1\% skim milk was used in nutrient agar medium) and autoclaved separately before pouring, content of both the flasks were mixed and then plates were poured. $100 \mu \mathrm{l}$ of $72 \mathrm{~h}$ old cell free supernatant of each isolates was added to each well cut on the prepoured skim milk agar. Plates were incubated at $28^{\circ} \mathrm{C}$ for $24-48 \mathrm{~h}$ and observed the clear zone production around the well. The proteolytic activity expressed in the terms of $\mathrm{mm}$ diameter of clear zones produced around the well after incubation at $28^{0} \mathrm{C}$ for $48 \mathrm{~h}$.

\section{Cellulase}

All the isolates were screened out for the cellulase activity on cellulose agar plates. Add $100 \mu \mathrm{l}$ of $72 \mathrm{~h}$ old culture supernatant in the well already cut on the pre poured cellulose agar plates with the help of sterile cork borer. Plates were incubated at $28^{\circ} \mathrm{C}$ for $24-72 \mathrm{~h}$ cellulase activity expressed in terms of $\mathrm{mm}$ diameter of clear zone produced around the well (Pathania et al., 2012).

\section{Chitinase}

All the isolates were screened out for production of chitinase and estimated by well plate assay on chitin agar plates $1 \%$ of colloidal chitin was added to nutrient agar. $100 \mu \mathrm{l}$ of $72 \mathrm{~h}$ old supernatant of bacterial isolates was added to well cut on the chitin plate. Plates were incubated at $28{ }^{0} \mathrm{C}$ for 3-7 days and observed for clear zone ( $\mathrm{mm}$ dia.) produced around the well (Queiene et al., 2008).

\section{Results and Discussion}

\section{Collection of rhizospheric soil samples}

The rhizosphric soil samples for PGPR's isolation were collected from rhizosphere of Triticum aestivum crop grown in its natural habitat at different location of Solan district of Mid Himalayan region of Himachal Pradesh, India, located at the different altitude above mean sea level in (Deothi (1502m), Kandaghat (1425m) and Dharja (1502m).

\section{Isolation of PGPR from rhizospheric soil}

PGPR isolates were isolated from the rhizospheric soil sample by serial dilution and spread plate method using different media i.e Nutrient agar, Jensen, Luria-Bertani and King's B agar medium at $28^{\circ} \mathrm{C}$. Nutrient agar media (Lapage et al., 1970) for bacteria present in the rhizosphere, Jensen for nitrogen fixing bacteria (Jensen, 1942; Ranganayaki et al., 1981), Luria-Bertani for Bacillus sp. (Lennox, 1955) and King's B agar for Pseudomonas sp. (King et al., 1954) specific media. The total viable count of rhizobacteria from Triticum aestivum from selected sites of Solan is represented in table 1.

The total rhizobacterial population on nutrient agar medium harboured the maximum (250x10 $15^{5} \mathrm{CFU} / \mathrm{g}$ soil) microbial population at Deothi, followed by Dharja $\left(165 \times 10^{5} \mathrm{CFU} / \mathrm{g}\right.$ soil) and Kandaghat (70x10 $0^{5} \mathrm{CFU} / \mathrm{g}$ soil) of district Solan. However, population of PGPR isolates on Jensen's medium was found highest at site Deothi $\left(200 \times 10^{5} \mathrm{CFU} / \mathrm{g}\right.$ soil), followed by Dharja (120x10 $\mathrm{CFU} / \mathrm{g}$ soil) and Kandaghat $\left(70 \times 10^{5} \mathrm{CFU} / \mathrm{g}\right.$ soil). In case of King's B agar, maximum rhizobacterial population was found at site Deothi $\left(230 \times 10^{5}\right.$ CFU/g soil), followed by Dharja $\left(170 \times 10^{5}\right.$ $\mathrm{CFU} / \mathrm{g}$ soil) and Kandaghat $\left(100 \times 10^{5} \mathrm{CFU} / \mathrm{g}\right.$ soil) In case of Luria-Bertani agar media, maximum rhizobacterial population was found at site Dharja $\left(180 \times 10^{5} \mathrm{CFU} / \mathrm{g}\right.$ soil), followed by Deothi $\left(102 \times 10^{5} \mathrm{CFU} / \mathrm{g}\right.$ soil $)$ and Kandaghat (19x10 $\mathrm{CFU} / \mathrm{g}$ soil) (Table 1).

The variation in the population of rhizobacteria may be attributed to location, 
age of plant, variety/cultivar type, time of sampling, physico-chemical and biological properties of soil and environmental conditions of the locations. The rhizosphere, considered to be a hot spot of bacterial diversity, harbours bacterial flora whose diversity is mainly expressed in terms of functions adapted to the root presence, and in particular to favour plant growth. This is in turn beneficial to the whole rhizosphere microbiota through the highly nutritive and energetically rhizodepositions (Aragno, 2005). Tamilarasi et al. (2008) reported that the varying degree of population observed in roots of the plant is due to the effect of chemical composition of root exudates of individual plants on the microorganisms.

\section{Morphological and physiological characterization of PGPR's isolated from rhizospheric soil of wheat}

In total, 60 PGPR's isolates were isolated on four different nutrient agar medium i.e. Nutrient agar, Jensen's media, King's B medium and Luria-Bertani agar. The morphological characters of bacterial isolates i.e. color, form, elevation and margins of bacterial isolates were noted down and presented in fig. $1,2 \& 3$.

\section{Deothi site}

The color of colonies of bacterial isolates from Deothi varied from white, milky white and yellow. Majority of isolates were white (46\%) in color, $29 \%$ were milky white in color, $21 \%$ isolates were off white and $4 \%$ yellow in color. $67 \%$ isolates are circular and $33 \%$ isolates were found puntiform in form. Out of total isolates, $54 \%$ isolates were raised while $46 \%$ had flat elevation. $62 \%$ bacterial isolates were gram positive and $38 \%$ were found to be gram negative (Fig 1).

\section{Kandaghat site}

The color of colonies of rhizobacterial isolates from Kandaghat varied from white, yellowish green and dark yellow. Majority of isolates were greenish yellow $(38 \%)$ in color, $37 \%$ were yellowish green in color, while $13 \%$ isolates were white and $12 \%$ were dark yellow in color. $63 \%$ isolates were circular and $37 \%$ isolates were puntiform in form. Out of total isolates, $50 \%$ isolates were raised while $50 \%$ had flat in elevation. $88 \%$ isolates were gram negative and $12 \%$ were found to be gram positive (Fig. 2).

\section{Dharja site}

The color of colonies of rhizobacterial isolates from Dharja varied from cream, yellow and white. Majority of isolates were cream $(67 \%)$ in color, $17 \%$ were found yellow in color and $16 \%$ isolates were white in color. $75 \%$ isolates were circular while $25 \%$ isolates were puntiform in form. Out of total isolates, $50 \%$ isolates were raised while $50 \%$ had flat elevation. $92 \%$ bacterial isolates were gram negative and $8 \%$ were found to be gram positive in nature (Fig 3).

\section{Deothi site}

\section{Phosphate solubilization}

Phosphate solubilization activity shown by bacterial isolates from Deothi was expressed in the range of 6 to $25 \mathrm{~mm}$ diameter of yellow zone on PVK agar plate. Out of twenty four isolates, only nineteen isolates showed Phosphate solubilization. Maximum Psolubilization was shown by the isolates De-5 and De-21 (25 $\mathrm{mm})$ followed by the isolate De-23 (24mm) and De-12 (20mm). Other isolates showed slightly less P-solubilization in the range of 6 to $18 \mathrm{~mm}$ dia. From Deothi site majority of the isolates were found positive for $\mathrm{P}$ - solubilization in-vitro conditions on PVK agar and some isolates were shown negative results for $\mathrm{P}$ solubilization. 


\section{Siderophore production}

The siderophore production of the all isolates from Deothi site was tested by qualitative method on CAS agar media. All the isolates were screened out for the siderophore production on chrome azurol-S (CAS) agar. The results were obtained qualitatively in the form of yellow colored zone (mm dia) produced around the well on chromazurol-S (CAS) agar plate at $28^{\circ} \mathrm{C}$ after $48 \mathrm{~h}$. The PGPR isolates from Deothi site showed the siderophore production in range of 9 to 14 $\mathrm{mm}$ diameter of zone produced on CAS agar. Out of twenty four isolates, twenty three isolates were found to produce the siderophore in plate assay.

Maximum siderophore production was shown by isolate De-4 $(14 \mathrm{~mm})$ followed by De-23 and De-20 $(13 \mathrm{~mm})$. From Deothi site majority of the isolates were found positive for siderophore production and some few isolates were shown negative results for siderophore production.

\section{HCN}

Isolates of PGPR from Deothi showed HCN production on nutrient agar medium amended with glycine. Out of twenty four isolates, maximum production of $\mathrm{HCN}(+++)$ was shown by De-21 to change the colour of filter paper strip yellow to brown. No $\mathrm{HCN}$ production was shown by other isolates from Deothi site. In case of $\mathrm{HCN}$ production majority of the isolates from Deothi site was shown results negative for $\mathrm{HCN}$.

\section{Ammonia}

The production of ammonia in peptone water after inoculation with test isolates and incubation for four days at $28^{0} \mathrm{C}$ was observed by using Nesseler's reagent. Color change in the broth tubes after growth from yellow to brown after addition of Nesseler's reagent showed presence of ammonia that was soluble in the media. Out of twenty four isolates, fourteen isolates showed maximum production of ammonia colour change from yellow to orange $(+++)$ while other isolates showed slightly less production of ammonia i.e colour change from yellow to light orange $(++)$. All the isolates from Deothi site were shown positive results for ammonia in different ranges $(++)$ to $(+++)$.

\section{Lytic enzymes}

\section{Protease}

Out of total 24 isolates, 21 isolates were found to be positive for protease production. Protease production was in the range of 18 $38 \mathrm{~mm}$ diameter of clear zone. Maximum production was shown by De- $8(38.0 \mathrm{~mm})$ followed by De-5, De-7 and De-21, De-6 $(35.0 \mathrm{~mm})$ and De-10 $(34.0 \mathrm{~mm})$ of clear zone. Other isolates showed the zone size in the range of $18-33 \mathrm{~mm}$.

\section{Chitinase}

Out of 24 isolates, only 7 isolates were found to be positive for chitinase production. Chitinase production was observed in the range of $8-20 \mathrm{~mm}$ diameter of clear zone. Maximum production was shown by isolates De-14, De-15 (20.0 $\mathrm{mm})$ followed by De-13 $(18.0 \mathrm{~mm})$ and De-3, De-17 (15.0 mm). Other isolates showed the zone size in the range of 6-8 $\mathrm{mm}$. Most of the isolates were found negative results for chitinase and some were found positive for chitinase production.

\section{Cellulase}

Out of total 24 isolates of PGPR, only 3 isolates were found to be positive for cellulase production. Cellulase production was shown in the range of 11-14 mm diameter of clear zone. Maximum production was shown by De-21 (14.0 mm) followed by De-5 (12.0 
$\mathrm{mm})$ and De-24 (11.0 mm). From Deothi site Majority of the isolates were found negative results for cellulase production, only three isolates were shown positive for cellulase production.

\section{Phosphate solubilization}

Phosphate solubilization activity shown by bacterial isolates from Kandaghat was expressed in the range of 11 to $32 \mathrm{~mm}$ diameter of yellow zone on PVK agar. Out of twenty four isolates, only seventeen isolates were shown phosphate solubilization. Maximum P-solubilization was shown by the isolates $\mathrm{Kn}-5(32 \mathrm{~mm})$ and followed by the isolate $\mathrm{Kn}-17(30 \mathrm{~mm}), \mathrm{Kn}-20(28 \mathrm{~mm})$ and $\mathrm{Kn}-19, \mathrm{Kn}-4$ (27 mm). Other isolates showed slightly less P-solubilization in the range of 11 to $26 \mathrm{~mm}$. From Kandaghat site most of the isolates were found positive for $\mathrm{P}$ solubilization.

\section{Siderophore production}

The isolates from Kandaghat site showed the siderophore production in range of 15 to 20 $\mathrm{mm}$ diameter of pink zone produced on CAS agar by qualitative method. Out of total twenty four isolates, twenty one isolates were found to produce the siderophore production. Maximum siderophore production was recorded for isolate $\mathrm{Kn}-14(20 \mathrm{~mm})$ followed by $\mathrm{Kn}-5(18 \mathrm{~mm})$ and $\mathrm{Kn}-9$ (17 mm). So from kandaghat site majority of the isolates were shown positive results for siderophore production.

Isolates of PGPR from Kandaghat showed HCN production on nutrient agar medium amended with glycine. Out of twenty four isolates, maximum production of $\mathrm{HCN}$ (++++) was shown by $\mathrm{Kn}-7$ to change the color of filter paper strip yellow to brown. No $\mathrm{HCN}$ production was shown by other isolates from Kandaghat site.

\section{Lytic enzymes}

\section{Protease}

Out of 24 isolates, 20 isolates were found to be positive for protease production. Protease production was in the range of $10-24 \mathrm{~mm}$ diameter of clear zone. Maximum production was recorded for $\mathrm{Kn}-2$ (24.0 mm) followed by isolates $\mathrm{Kn}-5(21.0 \mathrm{~mm})$ and $\mathrm{Kn}-1$ and $\mathrm{Kn}-7$ $(20.0 \mathrm{~mm})$ of clear zone. Other isolates showed the zone size in the range of 10-18 $\mathrm{mm}$ of clear zone. From Kandaghat site most of the isolates were found positive for protease production.

\section{Chitinase}

All the isolates from Kandaghat site were found to be negative for chitinase production, because chitinase enzyme was absent in these isolates.

\section{Cellulase}

All the isolates from Kandaghat were found to be negative for cellulase production, because cellulose enzyme was absent in these isolates.

\section{Phosphate solubilization}

Phosphate solubilization activity shown by bacterial isolates from Dharja was expressed in the range of 9 to $23 \mathrm{~mm}$ diameter of yellow zone on PVK agar. Out of twelve isolates, eleven isolates showed positive results for phosphate solubilization. Maximum Psolubilization was shown by the isolates Dh$12(23 \mathrm{~mm})$ followed by the isolate $\mathrm{Dh}-7, \mathrm{Dh}-$ $11(22 \mathrm{~mm})$ and Dh-10 (21 mm). Other isolates showed slightly less P-solubilization in the range of 9 to $20 \mathrm{~mm}$ diameter. Majority of the isolates from Dharja site showed Psolubilization in-vitro conditions. 


\section{Siderophore production}

The PGPR isolates from Dharja site showed the siderophore production in the range of 9 to $16 \mathrm{~mm}$ diameter of pink zone produced on CAS agar by qualitative method. Out of twelve isolates, eleven isolates were found to produce the siderophore. Maximum siderophore production was shown by isolate Dh-9 $(16 \mathrm{~mm})$ followed by Dh-8 $(15 \mathrm{~mm})$ and Dh-7 $(14 \mathrm{~mm})$. Most of the isolates were recorded positive for siderophore production by qualitatively.

\section{HCN}

Isolates of PGPR from Dharja showed HCN production on nutrient agar medium amended with glycine. Out of twelve isolates, nine isolates showed HCN production. Maximum production of $\mathrm{HCN}(++++)$ was shown by six isolates to change the color of filter paper strip yellow to brown. Three isolates produced in the range of $(+++)$. Majority of the isolates were recorded positive for $\mathrm{HCN}$ production in the range of light brown $(+++)$ to dark brown $(++++)$.

\section{Ammonia}

The production of ammonia in peptone water after inoculation with test isolates and incubation for four days at $28^{\circ} \mathrm{C}$ was observed by using Nessler's reagent. Color change in the broth tubes after growth from yellow to brown after addition of Nesseler's reagent showed presence of ammonia that was soluble in the media. Out of twelve isolates, six isolates showed maximum production of ammonia (+++) while other six isolates showed slightly less production of ammonia $(++)$. All the isolates from Dharja site were found positive for ammonia production.

\section{Lytic enzymes}

\section{Protease}

All the isolates were found to be positive for protease production. Protease production was found in the range of $25-35 \mathrm{~mm}$ diameter of clear zone. Maximum production was shown by Dh-7 $(35.0 \mathrm{~mm})$ followed by Dh-2, Dh-7, Dh-6 (33.0 mm) and Dh-1, Dh-5 and Dh-11 $(32.0 \mathrm{~mm})$ of clear zone.

All the isolates from Dharja site was found positive for protease production on skim milk agar.

\section{Chitinase}

Out of total 12 isolates, only 9 isolates were found to be positive for chitinase production. Chitinase production was recorded in the range of $8-20 \mathrm{~mm}$ diameter of clear zone. Maximum production was shown by $\mathrm{Dh}-4$, Dh-11 (20.0 mm) followed by Dh-3 (18.0 $\mathrm{mm})$. Majority of the isolates were recorded for chitinase production.

\section{Cellulase}

Out of 12 isolates only 3 isolates were found to be positive for cellulase production. Cellulase production was in the range of 10$13 \mathrm{~mm}$ diameter of clear zone. Maximum production showed by Dh-3 (13.0 mm) followed by Dh-7 (12.0 mm) and Dh-8 (10.0 $\mathrm{mm})$.

Most of the isolates were found negative for cellulase production on nutrient medium containing cellulose as a substrate. 
Table.1 Population density of rhizobacteria on different isolation media from sites Deothi, Kandaghat and Dharja of Solan District of Himachal Pradesh

\begin{tabular}{|c|c|c|c|c|c|c|c|c|c|c|c|c|}
\hline \multirow{4}{*}{$\begin{array}{lr}\text { Site } & \text { of } \\
\text { rhizospheric soil } \\
\text { sample collection }\end{array}$} & \multicolumn{12}{|c|}{ Total viable count on different nutrient medium } \\
\hline & \multicolumn{3}{|c|}{ Nutrient agar } & \multicolumn{3}{|c|}{ King's B agar } & \multicolumn{3}{|c|}{ Jensen media } & \multicolumn{3}{|c|}{ Luria Bertani agarl } \\
\hline & \multicolumn{2}{|c|}{ Dilutions } & \multirow{2}{*}{$\begin{array}{l}\text { cfu/g } \\
\text { soil } \times 10^{5}\end{array}$} & \multicolumn{2}{|c|}{ Dilutions } & \multirow{2}{*}{$\begin{array}{l}\text { cfu/g } \\
\text { soil } \times 10^{5}\end{array}$} & \multicolumn{2}{|c|}{ Dilutions } & \multirow{2}{*}{$\begin{array}{l}\text { cfu/g } \\
\text { soil } \times 10^{5}\end{array}$} & \multicolumn{2}{|c|}{ Dilutions } & \multirow{2}{*}{$\begin{array}{l}\text { cfu/g } \\
\text { soil } \times 10^{5}\end{array}$} \\
\hline & $10-^{4}$ & $10^{-6}$ & & $10^{-4}$ & $10^{-6}$ & & $10^{-4}$ & $10^{-6}$ & & $10^{-4}$ & $10^{-6}$ & \\
\hline Deothi & 250 & 40 & $250 \times 10^{5}$ & 230 & 110 & $230 \times 10^{5}$ & 200 & 60 & $200 \times 10^{5}$ & 102 & 69 & $102 \times 10^{5}$ \\
\hline Kandaghat & 70 & 15 & $70 \times 10^{5}$ & 100 & 65 & $100 \times 10^{5}$ & 70 & 36 & $70 \times 10^{5}$ & 19 & 7 & $19 \times 10^{5}$ \\
\hline Dharja & 165 & 53 & $165 \times 10^{5}$ & 170 & 68 & $170 \times 10^{5}$ & 120 & 59 & $120 \times 10^{5}$ & 180 & 78 & $180 \times 10^{5}$ \\
\hline
\end{tabular}

Table.2 Potential of bacterial isolates for different PGP attributes of site Deothi

\begin{tabular}{|c|c|c|c|c|c|c|c|c|}
\hline \multirow[t]{3}{*}{ Sr. no } & \multirow[t]{3}{*}{ Isolate } & \multirow{3}{*}{$\begin{array}{c}\begin{array}{c}\text { Siderophore } \\
\text { production }\end{array} \\
\text { Plate (mm dia) }\end{array}$} & \multirow{3}{*}{$\begin{array}{c}\text { Phosphate - } \\
\text { solubilization } \\
\text { Plate (mm dia) }\end{array}$} & $\mathbf{H C N}^{*}$ & Ammonia $^{* *}$ & \multirow{3}{*}{$\begin{array}{c}\text { Protease } \\
\text { Clear } \\
\text { zone } \\
\text { (mm } \\
\text { dia.) }\end{array}$} & \multirow{3}{*}{$\begin{array}{l}\text { Chitinase } \\
\text { Clear } \\
\text { zone }(\mathbf{m m} \\
\text { dia. })\end{array}$} & \multirow{3}{*}{$\begin{array}{c}\text { Cellulase } \\
\text { Clear } \\
\text { zone } \\
\text { (mm dia.) }\end{array}$} \\
\hline & & & & \multicolumn{2}{|c|}{$\begin{array}{c}\text { Change of color (yellow } \\
\text { to brown) }\end{array}$} & & & \\
\hline & & & & $\begin{array}{c}\text { (Paper } \\
\text { strip) }\end{array}$ & $\begin{array}{l}\text { (Culture } \\
\text { broth) }\end{array}$ & & & \\
\hline 1 & De-1 & 9 & 0 & - & ++ & 20.0 & 0.0 & 0.0 \\
\hline 2 & De-2 & 11 & 15 & - & +++ & 0.0 & 0.0 & 0.0 \\
\hline 3 & De- 3 & 12 & 0 & - & ++ & 29.0 & 15.0 & 0.0 \\
\hline 4 & De-4 & 14 & 15 & ++ & ++ & 22.0 & 0.0 & 0.0 \\
\hline 5 & De-5 & 12 & 25 & - & +++ & 35.0 & 8.0 & 12.0 \\
\hline 6 & De-6 & 12 & 18 & + & ++ & 34.0 & 6.0 & 0.0 \\
\hline 7 & De-7 & 11 & 10 & - & +++ & 35.0 & 0.0 & 0.0 \\
\hline 8 & De-8 & 10 & 0 & - & +++ & 38.0 & 0.0 & 0.0 \\
\hline 9 & De-9 & 0 & 6 & - & ++ & 26.0 & 0.0 & 0.0 \\
\hline 10 & De-10 & 9 & 8 & - & +++ & 33.0 & 0.0 & 0.0 \\
\hline 11 & De-11 & 9 & 10 & - & ++ & 34.0 & 0.0 & 0.0 \\
\hline 12 & De-12 & 9 & 20 & - & +++ & 27.0 & 0.0 & 0.0 \\
\hline 13 & De-13 & 10 & 15 & - & +++ & 20.0 & 18.0 & 0.0 \\
\hline 14 & De-14 & 12 & 0 & - & +++ & 22.0 & 20.0 & 0.0 \\
\hline 15 & De-15 & 9 & 10 & - & +++ & 30.0 & 20.0 & 0.0 \\
\hline 16 & De-16 & 8 & 12 & - & +++ & 26.0 & 0.0 & 0.0 \\
\hline 17 & De-17 & 10 & 8 & - & +++ & 25.0 & 15.0 & 0.0 \\
\hline 18 & De-18 & 9 & 0 & - & ++ & 0.0 & 0.0 & 0.0 \\
\hline 19 & De-19 & 11 & 12 & - & ++ & 18.0 & 0.0 & 0.0 \\
\hline 20 & De-20 & 13 & 13 & - & ++ & 0.0 & 0.0 & 0.0 \\
\hline 21 & De-21 & 12 & 25 & +++ & +++ & 35.0 & 0.0 & 14.0 \\
\hline 22 & De-22 & 10 & 10 & - & +++ & 30.0 & 0.0 & 0.0 \\
\hline 23 & De-23 & 13 & 24 & - & ++ & 29.0 & 0.0 & 0.0 \\
\hline 24 & De-24 & 12 & 15 & - & +++ & 26.0 & 0.0 & 11.0 \\
\hline C D ${ }_{0.05}$ & & 2.72 & 1.46 & - & - & 1.54 & 0.88 & 0.58 \\
\hline
\end{tabular}


Table.3 Potential of bacterial isolates for different PGP attributes of site Kandaghat

\begin{tabular}{|c|c|c|c|c|c|c|c|c|}
\hline \multirow[t]{3}{*}{$\begin{array}{l}\text { Sr. } \\
\text { no }\end{array}$} & \multirow[t]{3}{*}{ Isolate } & \multirow{3}{*}{$\begin{array}{l}\text { Siderophore } \\
\text { production } \\
\text { Plate (mm dia) }\end{array}$} & \multirow{3}{*}{$\begin{array}{l}\text { Phosphate } \\
\text { solubilization } \\
\text { Plate (mm dia) }\end{array}$} & $\mathrm{HCN}^{*}$ & Ammonia $^{* *}$ & \multirow{3}{*}{$\begin{array}{l}\text { Protease } \\
\text { Clear } \\
\text { zone } \\
(\mathrm{mm} \\
\text { dia. })\end{array}$} & \multirow{3}{*}{$\begin{array}{l}\text { Chitinase } \\
\text { Clear } \\
\text { zone (mm } \\
\text { dia.) }\end{array}$} & \multirow{3}{*}{$\begin{array}{l}\text { Cellulase } \\
\text { Clear } \\
\text { zone } \\
\text { (mm dia.) }\end{array}$} \\
\hline & & & & \multicolumn{2}{|c|}{$\begin{array}{l}\text { Change of color } \\
\text { (yellow to brown) }\end{array}$} & & & \\
\hline & & & & $\begin{array}{l}\text { (Paper } \\
\text { strip) }\end{array}$ & $\begin{array}{l}\text { (Culture } \\
\text { broth) }\end{array}$ & & & \\
\hline 1 & Kn-1 & 0 & 0 & - & ++ & 20.0 & 0.0 & 0.0 \\
\hline 2 & Kn-2 & 0 & 25 & - & ++++ & 24.0 & 0.0 & 0.0 \\
\hline 3 & Kn-3 & 16 & 0 & - & ++ & 0.0 & 0.0 & 0.0 \\
\hline 4 & Kn-4 & 15 & 27 & - & ++ & 15.0 & 0.0 & 0.0 \\
\hline 5 & Kn-5 & 18 & 32 & - & ++ & 21.0 & 0.0 & 0.0 \\
\hline 6 & Kn-6 & 0 & 24 & - & +++ & 16.0 & 0.0 & 0.0 \\
\hline 7 & Kn-7 & 15 & 25 & +++ & ++++ & 12.0 & 0.0 & 0.0 \\
\hline 8 & Kn-8 & 16 & 25 & - & ++ & 20.0 & 0.0 & 0.0 \\
\hline 9 & Kn-9 & 17 & 26 & - & ++++ & 10.0 & 0.0 & 0.0 \\
\hline 10 & Kn-10 & 15 & 23 & - & ++++ & 12.0 & 0.0 & 0.0 \\
\hline 11 & Kn-11 & 16 & 25 & - & ++++ & 16.0 & 0.0 & 0.0 \\
\hline 12 & Kn-12 & 15 & 16 & - & +++ & 0.0 & 0.0 & 0.0 \\
\hline 13 & Kn-13 & 16 & 0 & - & ++++ & 14.0 & 0.0 & 0.0 \\
\hline 14 & Kn-14 & 20 & 0 & - & +++ & 16.0 & 0.0 & 0.0 \\
\hline 15 & Kn-15 & 16 & 0 & - & ++++ & 18.0 & 0.0 & 0.0 \\
\hline 16 & Kn-16 & 15 & 11 & - & ++ & 12.0 & 0.0 & 0.0 \\
\hline 17 & Kn-17 & 16 & 30 & - & ++++ & 14.0 & 0.0 & 0.0 \\
\hline 18 & Kn-18 & 16 & 0 & - & ++++ & 17.0 & 0.0 & 0.0 \\
\hline 19 & Kn-19 & 15 & 27 & - & ++++ & 12.0 & 0.0 & 0.0 \\
\hline 20 & Kn20 & 16 & 28 & - & +++ & 0.0 & 0.0 & 0.0 \\
\hline 21 & Kn-21 & 16 & 25 & - & ++++ & 15.0 & 0.0 & 0.0 \\
\hline 22 & Kn-22 & 15 & 22 & - & +++ & 0.0 & 0.0 & 0.0 \\
\hline 23 & Kn-23 & 16 & 26 & - & ++++ & 18.0 & 0.0 & 0.0 \\
\hline 24 & Kn-24 & 16 & 16 & - & ++ & 12.0 & 0.0 & 0.0 \\
\hline $\begin{array}{l}\text { CD } \\
0.05\end{array}$ & & 1.54 & 1.43 & - & - & 1.50 & - & - \\
\hline
\end{tabular}


Table.4 Potential of bacterial isolates for different PGP attributes of site Dharja

\begin{tabular}{|c|c|c|c|c|c|c|c|c|}
\hline \multirow[t]{3}{*}{ Sr. no } & \multirow[t]{3}{*}{ Isolate } & \multirow{3}{*}{$\begin{array}{l}\text { Siderophore } \\
\text { production } \\
\text { Plate (mm dia) }\end{array}$} & \multirow{3}{*}{$\begin{array}{l}\text { Phosphate } \\
\text { solubilization } \\
\text { Plate (mm dia) }\end{array}$} & $\mathrm{HCN}^{*}$ & Ammonia $^{* *}$ & \multirow{3}{*}{$\begin{array}{l}\text { Protease } \\
\text { Clear } \\
\text { zone } \\
\text { (mm } \\
\text { dia.) }\end{array}$} & \multirow{3}{*}{$\begin{array}{l}\text { Cellulase } \\
\text { Clear } \\
\text { zone ( } \mathrm{mm} \\
\text { dia.) }\end{array}$} & \multirow{3}{*}{$\begin{array}{l}\text { Chitinase } \\
\text { Clear } \\
\text { zone } \\
\text { (mm dia.) }\end{array}$} \\
\hline & & & & \multicolumn{2}{|c|}{$\begin{array}{l}\text { Change of color } \\
\text { (yellow to brown) }\end{array}$} & & & \\
\hline & & & & $\begin{array}{l}\text { (Paper } \\
\text { strip) }\end{array}$ & $\begin{array}{l}\text { (Culture } \\
\text { broth) }\end{array}$ & & & \\
\hline 1 & Dh-1 & 12 & 12 & ++++ & ++ & 32.0 & 0.0 & 0.0 \\
\hline 2 & Dh-2 & 11 & 10 & ++++ & +++ & 33.0 & 0.0 & 12.0 \\
\hline 3 & Dh-3 & 9 & 20 & - & +++ & 25.0 & 13.0 & 18.0 \\
\hline 4 & Dh-4 & 0 & 20 & - & ++ & 31.0 & 0.0 & 20.0 \\
\hline 5 & Dh-5 & 14 & 9 & +++ & ++ & 32.0 & 0.0 & 15.0 \\
\hline 6 & Dh-6 & 11 & 0 & - & ++ & 33.0 & 0.0 & 0.0 \\
\hline 7 & Dh-7 & 14 & 22 & ++++ & +++ & 35.0 & 12.0 & 11.0 \\
\hline 8 & Dh-8 & 15 & 16 & ++++ & +++ & 32.0 & 10.0 & 8.0 \\
\hline 9 & Dh-9 & 16 & 19 & ++++ & ++ & 30.0 & 0.0 & 15.0 \\
\hline 10 & Dh-10 & 10 & 21 & +++ & +++ & 30.0 & 0.0 & 20.0 \\
\hline 11 & Dh-11 & 11 & 22 & +++ & ++ & 32.0 & 0.0 & 0.0 \\
\hline 12 & Dh-12 & 12 & 23 & ++++ & +++ & 29.0 & 0.0 & 13.0 \\
\hline$C D_{0.05}$ & & 1.62 & 1.62 & - & - & 1.65 & 0.74 & 1.47 \\
\hline
\end{tabular}

Plate.1 Collection of rhizospheric soil samples from Triticum aestivum rhizosphere from different sites of Solan district of Himachal Pradesh

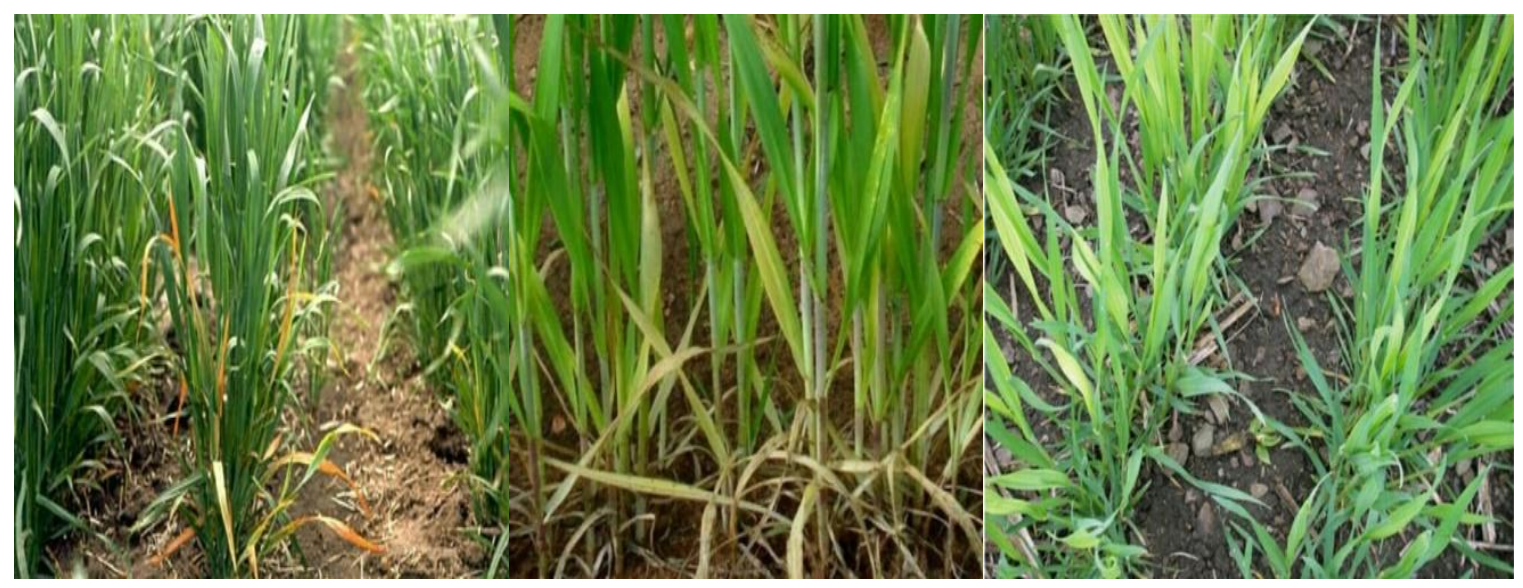


Plate.2 Total viable count of rhizobacteria from the rhizospheric soil of wheat on four different medium from Solan district
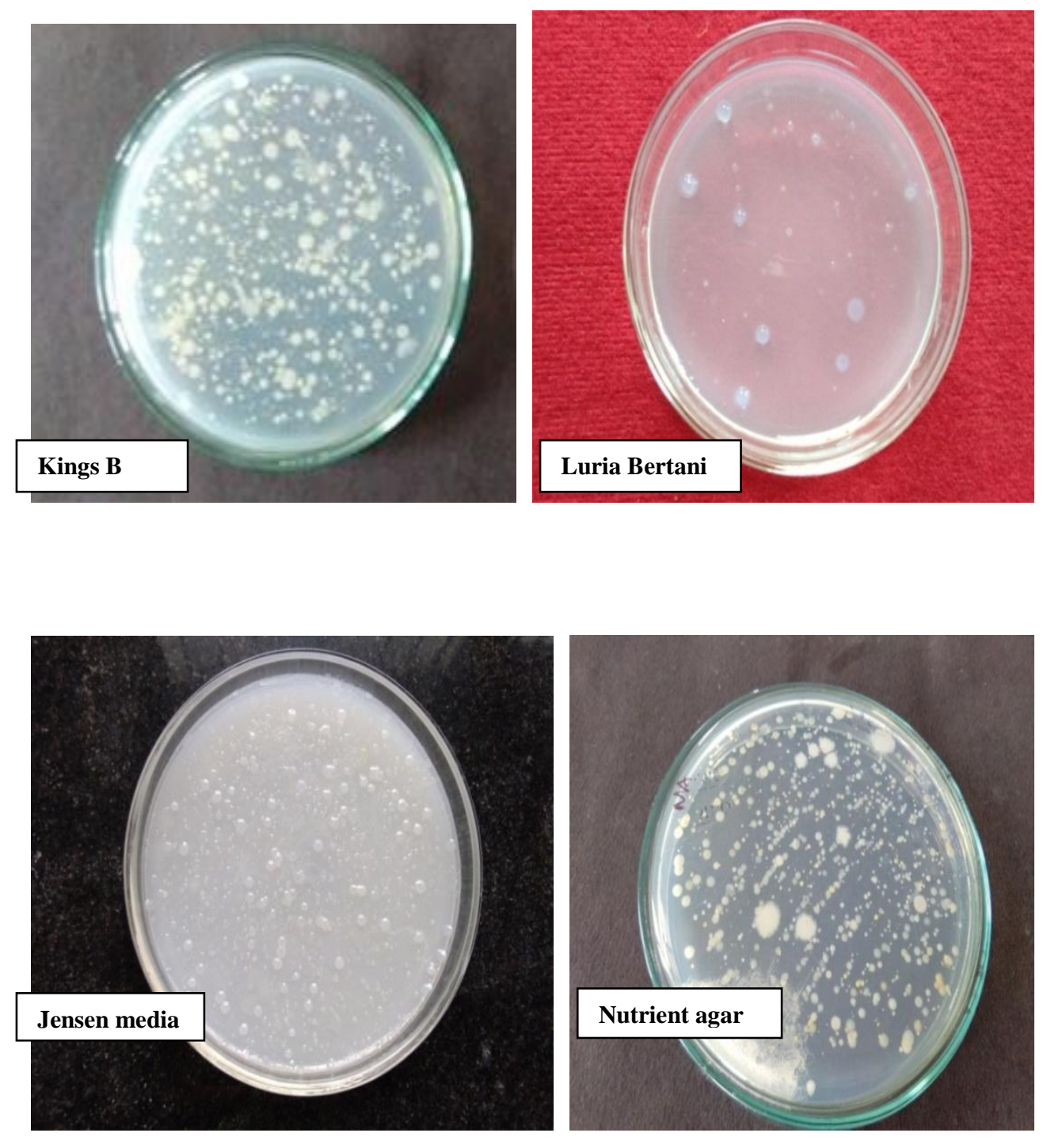
Fig.1 Morphological characteristics of rhizobacterial isolates from site Deothi
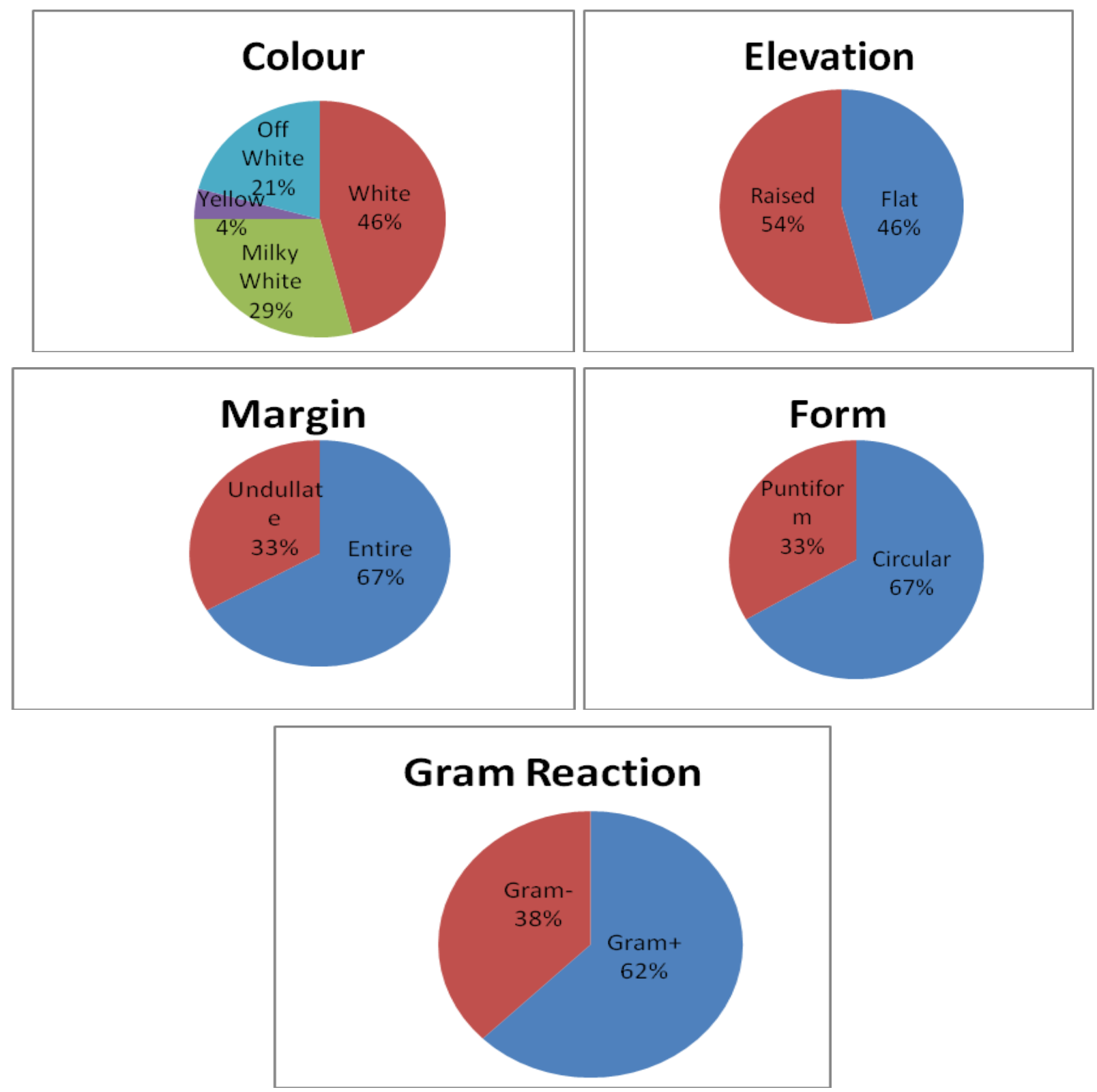
Fig.2 Morphological characteristics of bacterial isolates from site Kandaghat
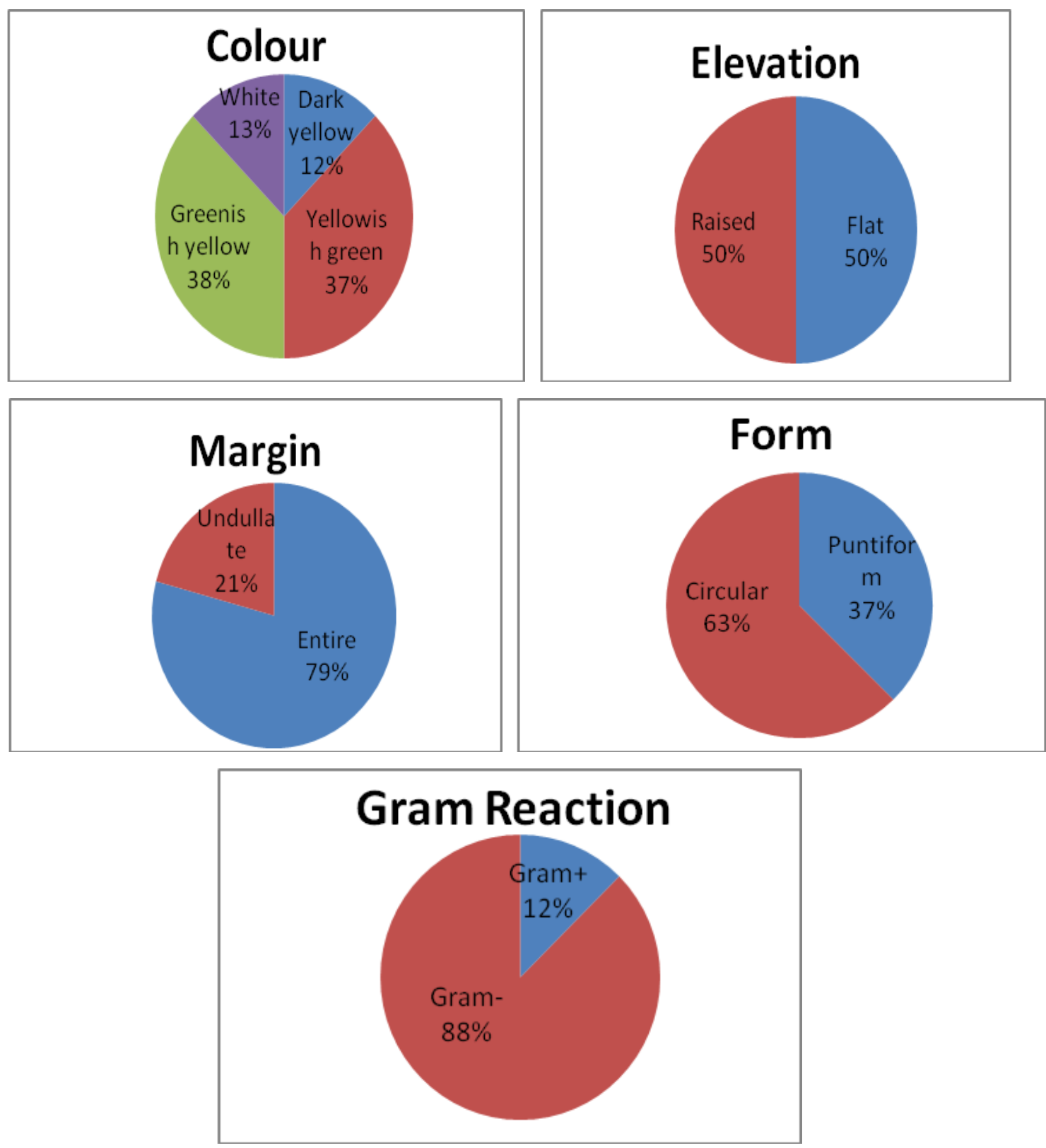
Fig.3 Morphological characteristics of bacterial isolates from site Dharja
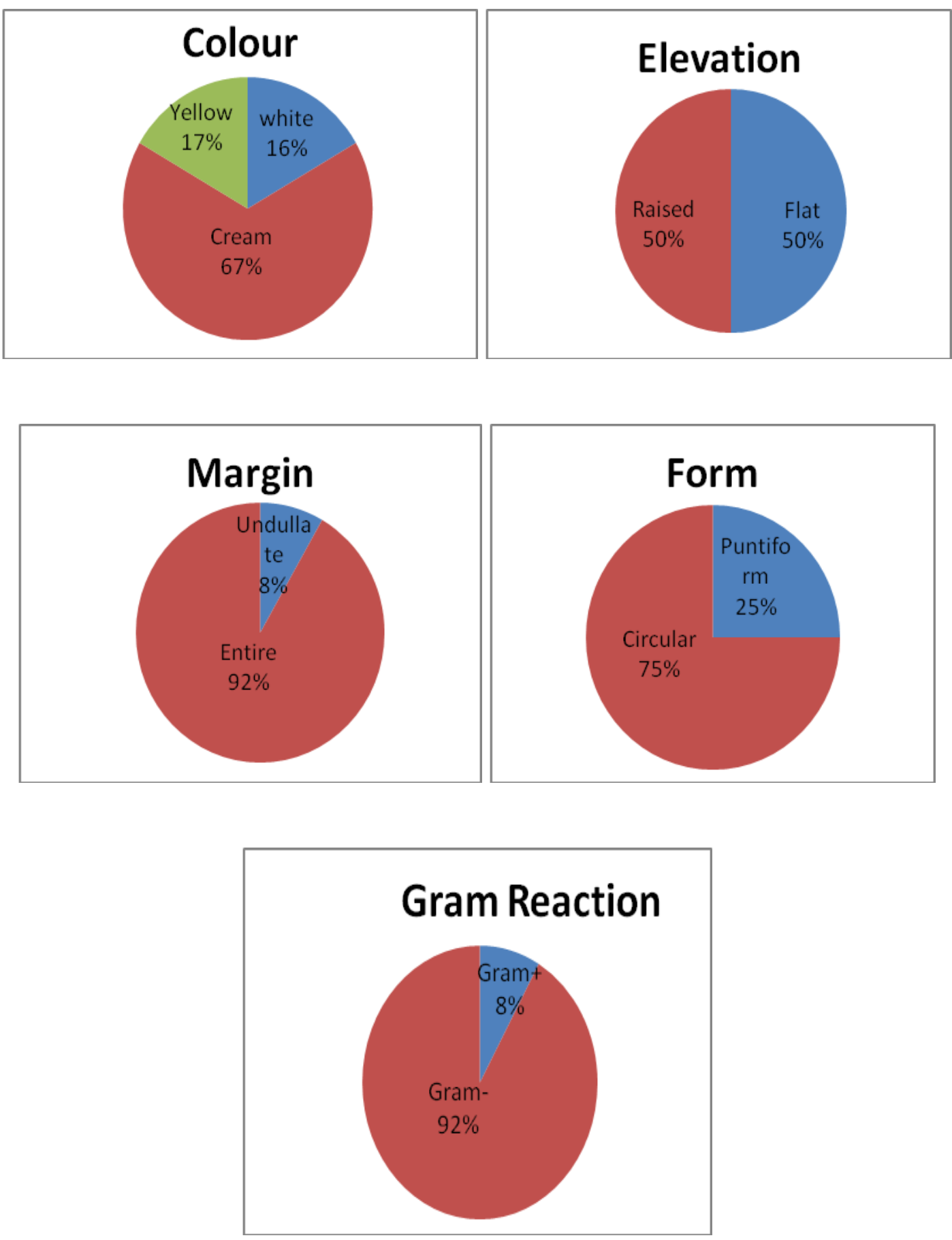

Total sixty isolates were recovered from the different three sites of Solan district (Deothi, Kandaghat and Dharja) of Himachal Pradesh. These isolates were isolated on the four different nutrient media. In case of elevation some were flat and few isolates were raised. Majority of isolates were entire and few were observed undulate in their margin. Most of the isolates were found circular and some were puntiform in their form. Out of total 
sixty isolates, majority of isolates were gram negative and few isolates were gram positive in nature. Majority of the isolates were found bacilli and fewer were cocci in their shape. Our results are in agreement with those from other investigations that found gram negative bacteria as main composition of rhizosphere and root associated microbial communities in many plant species (Joshi et al., 2006).

Thirty seven isolates were found positive for P- solubilization from these three sites. Phosphorus (P) is one of the major plant nutrients, that promote shoot and root growth of plants. Chemical fertilizers are main source for phosphorus supplying in agricultural systems but about $75-90 \%$ of added phosphorus to the soil is being fixed by $\mathrm{Fe}$, $\mathrm{Al}^{3+}$ and $\mathrm{Ca}^{2+}$ complexes (Tarun et al., 2006). Gupta (2012) also reported that the population of phosphate solubilizing microorganisms, in general, varied from $20-24 \%$ of the total population, however in some soils it may be $85 \%$ of the total population. In another studies conducted by Kundu et al., (2002) reported that about $16 \%$ of the total bacterial population in rhizosphere of wheat was Psolubilizer.

Out of total sixty isolates, fifty five isolates were recorded for siderophore production. Similar study was demonstrated that Acinetobacter calcoaceticus isolated from wheat rhizosphere produces catechol type of siderophores during exponential phase, which is influenced by iron content of medium (Sarode et al., 2009). The organisms used were siderophoregenic pyoverdin-producing Pseudomonas putida and Pseudomonas aeruginosa strains from two diverse habitats. Inoculation with siderophoregenic PGPR increased percentage germination, shoot height, shoot and root length, weight of spikelets, chlorophyll content, grain yield and iron content in wheat crop (Sarode et al., 2013; Mishra et al., 2013).
In case of ammonia all the isolates were showed positive results for ammonia production. Previous studies Chaiharn et al., (2008) reported the production of ammonia by phosphate solubilizing microorganisms, more than $64 \%$ of the isolates were found to produced ammonia. Another study by Ahmad et al., (2006) reported that the several plant growth promoting rhizobacteria were found to produce ammonia in peptone water amended with Nesseler's reagent.Only eleven isolates were showed positive results for $\mathrm{HCN}$ production. Although Hydrogen Cyanide acts as a general metabolic inhibitor, it is synthesized, excreted and metabolized by hundreds of organisms present in the rhizosphere mainly Plant Growth Promoting Rhizobacteria (PGPR) (Zeller et al., 2009). The similar study demonstrated that the HCN production is found to be a common trait of Pseudomonas (88.89\%) and Bacillus (50\%) in the rhizospheric soil of wheat a biocontrol metabolite in Pseudomonas species (Saharan and Nehra, 2011). Fifty three isolates were found positive for protease production. Protease a hydrolytic enzymes which suppress/ inhibit the growth of the bactrerial and fungal pathogens present in the rhizosphere of the plant. So the protease production by rhizobacteria is important attribute, all the isolates produced protease in good quantity. Similar study was reported by (Upadyay et al., 2013) some proteolytic enzymes especially elastase, subtilisin, pronase also possess bacteriolytic properties against different gram positive and gram negative bacteria. Cell wall-degrading enzyme protease secreted by biocontrol strains of PGPR exert a direct inhibitory effect on the hyphal growth of fungal pathogens by degrading their cell wall. In a similar manner, Bacillus cepacia synthesizes $\beta$-1,3-glucanase, which destroys the cell walls of the soil borne pathogens Rhizoctonia solani, Pythium ultimum, and Sclerotium rolfsii (Sadfi et al., 2005). 
Out of sixty isolates only sixteen isolates were found positive for chitinase production. Chitinase degrades chitin, an insoluble linear polymer of $\beta-1,4-\mathrm{N}$-acetyl-glucoseamine, which is the major component of the fungal cell wall. So the chitinase production by rhizobacteria is important attribute only seven isolates were produced chitinase. Those PGPR produce chitinase is a novel biological control agents because the cell wall of most of the fungal pathogens made up of chitin thus the cell wall of these pathogens is degraded by chitinase producer biological agents, so these isolates of PGPR were also act as biological control agents. Similar study was reported by (Jha and Saraf, 2015) potential biocontrol agents with chitinolytic activities include $B$. licheniformis, $B$. cereus, $B$. circulans, B. subtilis, and B. thuringiensis among the Gram-negative bacteria, Serratia marcescens, Enterobacter agglomerans, Pseudomonas aeruginosa, and Pseudomonas fluorescens have been found to possess chitinolytic activities. Only six isolates were recorded positive for cellulase production. Cellulase is also a hydrolytic enzymes which can degrade the cell wall of the lower fungal pathogens present in the rhizospheric region of plants. Most of the lower fungi cell wall is made up of cellulose a major constituent, thus these isolates were able to degrade the cell wall of plant pathogens having cellulose a major cell wall constituents. These isolates produced cellulose in appropriate quantity, showed different ranges of zone on the plate. The similar previous study was demonstrated that the cellulase synthesized by strains of Paenibacillus and Streptomyces spp. can easily degrade fungal cell walls of pathogenic F. oxysporum (Compant et al., 2005). In other crops the similar study was reported Viveknathan et al., (2004) studied that various kinds of enzymes (Cellulase, Chitinase and Protease) were produced by microorganisms. Lytic enzymes induced by Pseudomonas fluorescens and other biocontrol organisms mediated defence against the Anthracnose pathogen in mango leading to improved yield attributes.

It is concluded that, this is a basic study that has provided an insight into the bacterial community present in the mid hill zone of Himachal Pradesh, India .We have demonstrated efficient P-solubilizing, siderophore, ammonia, HCN and lytic enzymes producing bacteria present among the natural population. These characteristics are considered as important PGP traits and have been found effective in positively improving the growth and $\mathrm{N}$ contents of tested wheat plants. These isolates offer potentially in field applications as PGP agents in wheat.

\section{Acknowledgments}

Authors are thankfull to Dr. Y.S. Parmar University of Horticulture and Forestry Nauni, Solan (Himachal Pradesh), INDIA for funding the research work. Thanks are also due to the Head, Department of Basic Sciences, UHF Nauni- Solan Himachal Pradesh for providing the necessary facilities required for conducting the research work.

\section{References}

Aneja, K. R,. 2003. Experiments in microbiology, plant pathology and biotechnology. $4^{\text {th }}$ rev. ed. New Age International: New Delhi. 607 p.

Baker and Schippers. 1987. Microbial cyanide production in the rhizosphere in relation to potato yield reduction and Pseudomonas sp. mediated plant growth stimulation. Soil Biology and Biochemistry. 12: 57-60.

Glick, B. R. 1995. The enhancement of plant growth by free living bacteria. Canadian Journal of Microbiology. 41: 109-117.

Khan, S., M. Zaidi, A., and Wani, P. A. 2006. 
Role of phosphate solubilizing microorganism in sustainable agriculture- A review. Agrom. Sustain. Tev 27(1): 29-43.

Kumar, N. R., Arasu, J. T., and Gunasekaran, P. 2014. Genotyping of antifungal compounds. Canadian Journal of Microbiology. 43: 119-127.

Laegreid, M. Bockman, O. C. and Kaarstad, O. 1999. World cereal production challenges and opportunities. In: Agriculture fertilizers and environment, CABI publishing in association with Norsk Hydro ASA. UK. 219-234.

Lata and Saxena, A. K. 2003. Characterization of plant growth promoting rhizobacteria In: Training manual on biofertilizers technology. Saxena A K (ed.). IARI: Delhi. pp. 2425.

Mehta, V. J., and Singh, S. P. 2006. Production of alkaline Protease from an alkaliphilic actinomycete . Bioresource Technology. 97(14): 1650-1654.

Mishra, B., Chatrath, R., Mohan, D., Saharan, M. S., and Tyagi, B.S. 2007. DWR Prespective Plan: 2025. Directorate of Wheat Research. Karnal. India. P. 1415.

Nelson, L. M. 2004. Plant growth promoting rhizobacteria (PGPR): Prospects for new inoculants. Online. Crop Management. 10: 10-19

Pathania, S., Sharma, N., and Verma, S. 2012. Optimization of cellulose free xylanase produced by a potential the alkalophillic Paenibacillus sp N1 isolated from hot spring of Northern Himalayas in India. The journal of Microbiology, Biotechnology and Food sciences. 2 (1): 1-24.

Pikovsakaya, R. E.1948. Mobilization of phosphorus in soil in connection with vital activity of some microbial species .Microbiologia. 17: 362-370.

Queiene, M. C., Araujo, W. L., Marcon, J., Gai, M.C., Azevedo, J. Z., and PizziranKleiner, A. 2008. Chitinolytic activity of endophytic streptomycs and potential for biocontrol. Letters in Applied Microbiology. 47(60):486-491.

Schwyan, B., and Neilands, J. B. 1987. Universal chemical assay for the detection and determination of siderophores. Analytic Biochemistry. 28(8): 751-759.

Somasegaran, P., Hoben, H. J. 1994. Hand book for Rhizobia Methods in Legume -Rhizobium Technology. New York: Springer- Verleg. 240 -58.

Van Loon, L. C., Bakker, P. A., Pieterse, C. M. J. 1998. Systemic resistance induced by Rhizosphere bacteria. Annl Rev Phytopathol. 36: 453-483.

Welton Taylor, I., and David Achanzar. 1972. Catalase test as an aid to the identification of Enterobacteriaceae. Applied and Environmental Microbiology. 24(1):58-61.

\section{How to cite this article:}

Vijay Kumar, Nivedita Sharma and Kuchay, M. A. 2020. Diversity and Characterization of Plant Growth Promoting Rhizobacteria Associated with Wheat (Triticum aestivum) Rhizosphere in North-Western Himalayan State of Himachal Pradesh in India. Int.J.Curr.Microbiol.App.Sci. 9(03): 747-764. doi: https://doi.org/10.20546/ijcmas.2020.903.090 